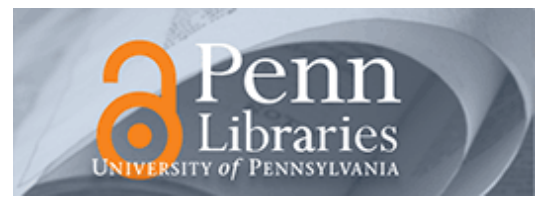

University of Pennsylvania

ScholarlyCommons

Accounting Papers

Wharton Faculty Research

6-2005

\title{
Economic Consequences of SEC Disclosure Regulation: Evidence From the OTC Bulletin Board
}

Brian J. Bushee

University of Pennsylvania

Christian Leuz

Follow this and additional works at: https://repository.upenn.edu/accounting_papers

Part of the Accounting Commons, and the Finance and Financial Management Commons

\section{Recommended Citation}

Bushee, B. J., \& Leuz, C. (2005). Economic Consequences of SEC Disclosure Regulation: Evidence From the OTC Bulletin Board. Journal of Accounting and Economics, 39 (2), 233-264. http://dx.doi.org/10.1016/ j.jacceco.2004.04.002

This paper is posted at ScholarlyCommons. https://repository.upenn.edu/accounting_papers/126

For more information, please contact repository@pobox.upenn.edu. 


\title{
Economic Consequences of SEC Disclosure Regulation: Evidence From the OTC Bulletin Board
}

\begin{abstract}
This paper examines the economic consequences of a regulatory change mandating OTCBB firms to comply with reporting requirements under the 1934 Securities Exchange Act. This change substantially increases mandated disclosures for firms previously not filing with the SEC. We document that the imposition of disclosure requirements results in significant costs for smaller firms, forcing them off the OTCBB. SEC regulation also has significant benefits. Firms previously filing with the SEC experience positive stock returns and permanent increases in liquidity, suggesting positive externalities from disclosure regulation. Newly Compliant firms exhibit significant increases in liquidity consistent with improved disclosure reducing information asymmetry.
\end{abstract}

\section{Keywords}

mandatory disclosure, enforcement externalities, over-the-counter market, liquidity, listing choices, eligibility rule

\section{Disciplines}

Accounting | Finance and Financial Management 
Forthcoming Journal of Accounting and Economics 39 (2), 2005

\title{
Economic consequences of SEC disclosure regulation: Evidence from the OTC bulletin board
}

\author{
Brian J. Bushee, Christian Leuz
}

The Wharton School, University of Pennsylvania, Philadelphia, PA 19104, USA

Received 28 February 2002; received in revised form 2 April 2004; accepted 7 April 2004

\begin{abstract}
This paper examines the economic consequences of a regulatory change mandating OTCBB firms to comply with reporting requirements under the 1934 Securities Exchange Act. This change substantially increases mandated disclosures for firms previously not filing with the SEC. We document that the imposition of disclosure requirements results in significant costs for smaller firms, forcing them off the OTCBB. SEC regulation also has significant benefits. Firms previously filing with the SEC experience positive stock returns and permanent increases in liquidity, suggesting positive externalities from disclosure regulation. Newly compliant firms exhibit significant increases in liquidity consistent with improved disclosure reducing information asymmetry.
\end{abstract}

JEL classification: G18; G38; K22; G39; M44; G14

Keywords: $\quad$ Mandatory disclosure; Enforcement; Externalities; Over-the-counter market; Liquidity; Listing choices; Eligibility rule

We would like to thank Stan Baiman, Sudipta Basu, John Core, Leslie Hodder, Alan Jagolinzer, Mike Kirchenheiter, S.P. Kothari (the editor), Bill Tyson, Laurence van Lent, Ronnie Sadka, Mohan Venkatachalam (the referee), Ro Verrecchia, Greg Waymire, Joe Weber, and Peter Wysocki, for helpful comments and suggestions. The paper has benefited from presentations at the AFA annual meeting, American University, the EAA annual meeting, Emory University, University of North Carolina, Oklahoma State University, Penn State University, Securities and Exchange Commission (OEA), Tulane University, Winter Accounting Conference (University of Utah), and the Wharton School. We are particularly thankful to Yim Cheung (Pink Sheets) and Greg Ballard (Knobias) for generously providing data for our study. In addition, we are grateful to Liz Hesse (NASDAQ) and numerous market makers for helpful discussions of institutional details, and Gerry Cooke (Thomson Financial Datastream) and Pete Healy (Mergent) for their assistance with data issues. Finally, we thank Brian Lempel, Darwin Rodriguez, and Richard Clattenburg for their research assistance.

*Corresponding author. Present address: The Wharton School, 2400 Steinberg-Dietrich Hall, University of Pennsylvania, Philadelphia, PA 19104-6365, USA; Phone: +1-215-898-2610; fax: +1-215-573-2054

E-mail address: leuz@wharton.upenn.edu (C. Leuz) 
1. Introduction

Extensive SEC disclosure regulation and enforcement are often viewed as cornerstones of US capital markets (Sutton, 1997; Levitt, 1998). However, there is surprisingly little evidence on the alleged costs and benefits of disclosure regulation (Healy and Palepu, 2001). Moreover, the economic consequences of mandatory disclosures are theoretically far from clear and heavily debated (e.g., Coffee, 1984; Easterbrook and Fischel, 1984).

We contribute evidence to this debate by examining firm-specific consequences of SEC disclosure regulation for a sizable and previously unregulated US market segment. By disclosure regulation, we mean mandatory reporting obligations and the enforcement of these obligations. We exploit a recent regulatory change mandating firms quoted on the Over-The-Counter Bulletin Board (OTCBB) to comply with the reporting requirements under the 1934 Securities Exchange Act. We study firms' responses and market reactions to provide evidence on firm-specific costs and benefits, but do not evaluate the regulator's decision or the net social costs or benefits.

We find that the imposition of SEC disclosure requirements has two effects on firms not previously filing with the SEC. First, it forces a substantial number of firms into a less regulated market, at significant costs in terms of market value and liquidity. Second, a quarter of firms is compelled to adopt SEC disclosures to avoid removal from the OTCBB. Even though these firms experience significant increases in liquidity upon compliance, stock returns suggest that the regulatory change is costly to these firms. The evidence further suggests that these two effects create positive externalities for OTCBB firms that were already compliant with SEC disclosure requirements, possibly due to liquidity spillovers or an enhanced reputation of the OTCBB.

On January 4, 1999, the SEC approved the "eligibility rule," which required all domestic OTCBB firms to comply with the reporting obligations under the 1934 Act by a firm-specific 
phase-in date between July 1999 and June 2000. Prior to this rule, securities could be traded on the OTCBB without SEC filing if the firm (1) had \$10 million or less in total assets or fewer than 500 owners of record and (2) had avoided registering securities under the 1933 Securities Act. ${ }^{1}$ Firms merely had to provide financial statements to a market maker once to initiate quotation, but not subsequently. Prior to the eligibility rule, the OTCBB quoted over 3,600 firms that did not file with the SEC. For these firms, the new rule substantially extended the disclosures required for trading in the OTCBB.

The regulatory change created three firm groups. For firms that were not filing with the SEC prior to the eligibility rule, the costs presumably exceeded the benefits; otherwise they could have voluntarily filed with the SEC. By eliminating the possibility to trade on the OTCBB without filing, the eligibility rule essentially forces these firms to choose their next-best alternative. Firms that do not to comply with SEC reporting are removed from OTCBB ("Noncompliant" firms). These firms have to go private or trade in the Pink Sheets, where SEC filing is not required. Firms that prefer to continue trading in the OTCBB must adopt SEC disclosures ("Newly Compliant" firms). Thus, the compliance responses of both groups, and the market reactions to them, provide evidence on firm-specific costs and benefits from the imposition of mandatory disclosures. Firms that were already subject to SEC reporting obligations, either due to their size and number of shareholders or due to prior securities offerings under 1933 Act, were not directly affected by the eligibility rule ("Already Compliant" firms). These firms provide an opportunity to study externalities of disclosure regulation.

1 See Section 2 for more details. Note also that the number of owners of record is not the number of actual shareholders and that the latter can be much larger. Shares held by a brokerage firm or clearinghouse count as having one owner of record even though the shares are owned by many different shareholders. 
We document that over 2,600 (or 76\%) of the firms not previously filing with the SEC did not comply with the required disclosures and hence were removed from the OTCBB. Thus, for the vast majority of OTCBB firms, the costs of mandatory SEC disclosures appear to outweigh the benefits. We also examine firm characteristics, such as size, ownership structure, outside financing needs, and profitability. These characteristics are typically associated with costs and benefits of disclosures such as liquidity, cost of capital, agency costs, access to financing, and proprietary costs (e.g., Lang and Lundholm, 1993 and 2000). We find that Noncompliant firms are smaller, less leveraged, and more profitable than Newly Compliant firms. These results have to be interpreted cautiously as data availability prior to the eligibility rule is limited, but they suggest that an important consequence of mandatory SEC disclosures is to push smaller firms with lower outside financing needs into a less regulated market, rather than to compel them to adopt higher disclosure standards.

Next, we examine stock returns around the announcement and implementation of the eligibility rule to provide evidence on the market's assessments of the costs or benefits resulting from the imposition of SEC disclosures. We find positive abnormal returns for Already Compliant firms around key announcements and phase-in dates, suggesting positive externalities from the imposition of mandatory disclosures on other firms. Newly Compliant firms exhibit significantly lower returns than Already Compliant firms at the key announcement dates. This result is consistent with the eligibility rule forcing Newly Compliant firms to adopt their secondbest alternative, as they can no longer trade on the OTCBB without filing with the SEC. Noncompliant firms exhibit even lower returns around the key announcement dates. Moreover, they experience significantly negative abnormal returns upon removal from the OTCBB. These findings indicate that the imposition of disclosure requirements has significant costs for firms 
that previously did not file with the SEC and particularly for those firms forced into a less recognized and less liquid market.

Finally, we examine changes in firms' market liquidity around the phase-in of the eligibility rule to provide evidence on an important mechanism through which disclosure regulation affects firms. Prior studies suggest that liquidity is priced in returns (e.g., Amihud and Mendelson, 1986; Brennan et al., 1998; Chordia et al., 2001). Consistent with these studies and our return results, we find that Noncompliant firms experience significant and sustained decreases in all liquidity measures after their removal from the OTCBB. Newly Compliant firms experience significant increases in liquidity, which are significantly larger than for the other groups. However, the liquidity benefits do not imply that imposing SEC disclosures made these firms better off overall; the documented announcement returns and the non-disclosure strategy prior to the eligibility rule suggest the opposite. Already Compliant firms exhibit significant and sustained increases in liquidity for two of three measures. This finding suggests improved liquidity as a possible source of externalities. It may also reflect increases in demand for Already Compliant firms after the removal of Noncompliant firms, if some small cap investors are unwilling to trade in the Pink Sheets. Overall, the liquidity analysis corroborates the results for firms' compliance responses and stock returns.

This paper contributes to a fairly limited empirical literature on the economic consequences of disclosure regulation. $^{2}$ According to Healy and Palepu (2001, p. 415), empirical research on

2 There is a vast literature on the economic consequences of mandated changes in accounting standards (Watts and Zimmerman, 1986; Fields, Lys, and Vincent, 2001). This literature, along with capital-markets research in accounting, generally focuses on the relation between reported accounting numbers and stock returns (or prices), thereby providing evidence on whether the required numbers add value to investors (see also Kothari, 2001). However, these studies occur within the already-rich SEC disclosure environment, whereas our study analyzes the imposition of SEC disclosure requirements. There are also studies on the properties of accounting numbers prior to the introduction to SEC regulation, but not its imposition (e.g., Sivakumar et al., 2003). 
disclosure regulation is "virtually non-existent." Early studies by Stigler (1964) and Benston (1969 and 1973) investigate the benefits of the Securities Acts and conclude that the statutes were of no apparent value to investors. These early studies have been heavily debated and challenged (see Coffee, 1984, for a survey). We examine a more recent expansion of disclosure regulation and show that the imposition of SEC disclosure requirements results in significant costs and benefits to firms that were forced to change their disclosure policies. Moreover, we provide some evidence on the existence of externalities, which are commonly viewed as a justification for regulation.

Our paper also contributes to the understanding of the OTC Bulletin Board, a market that has been largely ignored by prior research. The only paper to examine this market as a whole is Luft et al. (2001). They find that, prior to the eligibility rule, OTCBB securities yield lower returns with higher risk than securities listed on major exchanges. They attribute these results to the lack of information and liquidity in the OTCBB. Our paper provides evidence on the liquidity of this market and how it changes around the introduction of disclosure requirements.

The next section reviews prior work on the economics of disclosure regulation and explains how we exploit the OTCBB setting to contribute to this literature. Section 3 develops our hypotheses. In Section 4, we explain the construction of the key samples and examine firms' listing responses to the eligibility rule. Section 5 discusses the results for firms' stock returns. Section 6 reports the findings for changes in liquidity measures. Section 7 concludes the paper.

\section{Prior Studies and the Institutional Setting}

The costs and benefits of mandating disclosures are not obvious because, as firms ultimately bear the costs of withholding information, they have private incentives to provide information voluntarily. One potential role of mandatory disclosure is to serve as a commitment device. 
Disclosures reduce the firm's cost of capital, but only if they are credible and not self-serving. Without commitment, firms may have incentives to withhold or manipulate information in certain situations, e.g., when performance is poor. Mandatory disclosures bind firms to reveal information in both good and bad times (e.g., Verrecchia, 2001). ${ }^{3}$

Externalities provide a second rationale for mandatory disclosure regimes. They arise whenever the social and private values of information differ. In such a case, firms trading off the private costs and benefits do not provide the socially optimal level of disclosure. Hirshleifer (1971) argues that private information acquisition for speculative gains in securities markets is socially wasteful. On the other hand, private monitoring creates free-rider problems by conferring uncompensated benefits on other investors (e.g., Coffee, 1984). Thus, disclosure regulation can mitigate both the over- and underproduction of information and, hence, be socially desirable. Dye (1990) and Admati and Pfleiderer (2000) argue that firms' disclosures have positive externalities in the form of information transfers and liquidity spillovers. With correlated firm values or cash flows, information disclosed by one firm can be useful in valuing other firms and increase investors' willingness to hold positions in other firms. But disclosures can also have negative externalities if investors (or analysts) follow only a limited number of firms, e.g., due to information processing costs. Fishman and Hagerty (1989) argue that, in imperfectly competitive markets, increases in disclosure can attract investors away from other firms, resulting in lower price efficiency.

The preceding discussion suggests that the effects of disclosure regulation are complex. They are further complicated by the fact that firms have various ways to respond to disclosure

3 Such requirements can be provided privately, for instance, by an exchange in the form of a listing agreement, or publicly by a regulatory act. Huddart et al. (1999) show that exchanges competing for liquidity have incentives to set tough disclosure standards and generally do not engage in a 'race to the bottom'. 
regulation. For instance, firms can choose to trade in a different market, go private, or not go public. For these reasons, empirical studies of firms' responses and market reactions to disclosure regulation provide valuable input into regulatory decisions.

Early studies by Stigler (1964) and Benston (1969 and 1973) conclude that the 1933 and 1934 Acts were of no apparent value to investors, but these findings have been repeatedly challenged (e.g., Friend and Herman, 1964; Seligman, 1983). Coffee (1984) reviews the inconclusive debate and argues that the focus should be shifted to contemporary securities regulation as much has changed since the 1930s. ${ }^{4}$ Addressing this void, our study exploits a recent regulatory act in the over-the-counter markets that affected more than 3,500 firms and examines the aforementioned key aspects of disclosure regulation: market reactions, firms' responses, and externalities.

The OTC Bulletin Board (OTCBB) is an electronic quotation medium for small-cap securities not traded on NASDAQ or listed on one of the national exchanges. The OTCBB is operated and regulated by the National Association of Securities Dealers (NASD) and it provides real-time quotes, last-sales prices, and volume information. It was established in June 1990, partially in response to the Penny Stock Reform Act of 1990. This Act mandated the creation of an electronic system to provide widespread quotation and trade information, thereby increasing price transparency in the OTC market. By 1998, more than 6,000 domestic issues were quoted on the OTCBB with an average daily trading volume over $\$ 200$ million and an estimated market capitalization of over $\$ 50$ billion. Thus, the OTCBB represents a sizeable segment of the U.S. securities market.

4 Recent work by Greenstone et al. (2003) examines the 1964 Securities Acts Amendments and documents positive abnormal stock returns for affected firms, which they attribute to an agency cost explanation. 
In contrast to the NASDAQ market, there are no listing requirements or quotation fees on the OTCBB. Firms can simply approach a market maker for sponsorship. Market makers are prohibited from accepting any remuneration for their quotation services from the issuers. The OTCBB is also distinct from the Pink Sheets, another over-the-counter market segment, which did not provide electronic quotations until September 1999 and a supporting web portal until June 2000. The Appendix provides a summary comparison of the market characteristics, disclosure requirements, and enforcement rules of these three markets.

Before January 1999, issuers on the OTCBB did not have to file periodic financial reports with the SEC if they (1) had never registered securities under the 1933 Act and (2) were below the thresholds specified in Section $12(\mathrm{~g})$ of the 1934 Act. Firms with security offerings registered under the 1933 Act are mandated by Section 15(d) to comply with the periodic reporting obligations of the 1934 Act. $^{5}$ Section $12(\mathrm{~g})$ stipulates that issuers with total assets exceeding \$10 million and a class of security held by more than 500 owners of record on the last day of the fiscal year must register their securities under the 1934 Act. While the ownership limit appears to be quite restrictive, the rule refers only to "owners of record" and not the number of actual shareholders. The latter can be much higher because shares are often held in "street name" by a brokerage firm or clearinghouse, which counts only as one owner (WSJ, 7/28/2003).

Exemptions from registration under the 1933 Act, as well as size and ownership limits in Section 12(g), implied that over half of the companies quoted on the OTCBB in 1998 were not subject to SEC reporting requirements (SEC Adopting Release 34-40878). For these firms, the only reporting requirements stemmed from SEC Rule 15c2-11. This rule mandates that any

$5 \quad$ Firms can use various exemptions to avoid registration under the 1933 Act. For instance, rule 504 of Regulation D allows issuers to sell up to $\$ 1$ million of stock without registration under the 1933 Act. 
broker/dealer initiating a quotation obtain current financial reports (e.g., balance sheet and income statement) from the issuer. After 30 days, the stock becomes eligible for the "piggyback" exemption, which allows other market makers (including the initiating market maker) to issue quotes without having updated financial information. For this reason, financial reports were generally not publicly available for those firms not required to file with the SEC (WSJ, 12/9/1997). ${ }^{6}$ Moreover, Rule 15c2-11 does not require financial reports to be audited and demands far fewer disclosures than SEC Form 10-K.

In the late 1990's, the SEC and the NASD jointly considered improving the disclosure of financial information by OTCBB firms. There was a resurgence of OTC securities fraud and the relatively unregulated OTCBB was perceived as exacerbating the problem (WSJ, 9/4/1997). ${ }^{7}$ In addition, the NASD was concerned that investors could confuse the OTCBB with its more highly regulated NASDAQ market and that real-time quotations gave unwary investors a false sense of reliability, particularly considering the lack of disclosure requirements (WSJ, 12/9/1997). In February 1998, the NASD Board of Governors proposed to restrict quotations on the OTCBB to those domestic companies that report current financial information to the SEC, banking, or insurance regulators. After public comment, the so-called "eligibility rule" was approved by the NASD in May 1998 and submitted to the SEC for approval.

On January 4, 1999, the SEC approved the eligibility rule as amendments to NASD rules 6530 and 6540. It limits quotations on the OTCBB to securities of issuers that make current filings pursuant to Sections 13 and 15(d) of the 1934 Act, and securities of depositary institutions

6 We confirmed this claim in interviews with officials from NASDAQ, the SEC, and several OTC market makers. Note that any availability of information prior to the eligibility rule biases our results against finding significant reactions and changes.

7 State regulators estimate that investor losses due to penny stock abuses amounted to $\$ 6$ billion annually during the 1990's (WSJ, 9/22/1997). Anecdotal evidence also suggests that there is a significant number of small retail investors trading in the OTC markets. 
and insurance companies that make filings under the Act, but with the appropriate regulatory agencies. The eligibility rule implies that OTCBB companies have to file annual reports using Form 10-K as well as quarterly and current reports using Form 10-Q and 8-K, respectively. Moreover, the filings are made easily accessible through the SEC's EDGAR database. Thus, the eligibility rule considerably increases mandatory disclosures for firms that were previously not filing with the SEC. In addition, it creates civil liabilities under Section 18 and brings firms' reporting under the auspices of the SEC (e.g., Section 15(c)(4) compliance orders). Thus, the eligibility rule substantially increases private and public enforcement of disclosures.

The eligibility rule became immediately effective for new OTCBB quotations, but provided a phase-in period for issuers with securities quoted as of January 4, 1999. Each issuer was assigned a phase-in date between July 1999 and June 2000 based on its ticker symbol as of January 4, 1999. The implementation schedule gave companies between 6 and 18 months after the rule's approval to become current in their filing with the SEC. Between 100 and 300 firms were tested for compliance at each phase-in date, and all but the first three months had two phase-in dates. Filing status was reviewed in an initial compliance test 30 days prior to the phase-in date (60 days prior for banks and insurance companies). If the NASD did not have information establishing that the issuer was current in its filings with the SEC, it appended an "E" as fifth character to the ticker symbol to flag non-compliance with the eligibility rule. If the company subsequently became compliant with the eligibility rule, the "E" was eliminated; otherwise, the issuer was removed from the OTCBB on the day after the phase-in date.

\section{Hypothesis Development and Research Design}

As explained in the previous section, the eligibility rule mandates a substantial increase in the amount and enforcement of required disclosures for the majority of OTCBB firms. The rule 
eliminates the possibility to trade on the OTCBB without making the required disclosures, forcing firms to either comply with SEC disclosure requirements or to leave the OTCBB. In responding to the rule, firms are expected to tradeoff the costs and benefits of mandatory disclosures, SEC scrutiny and enforcement, and extended legal liability. Thus, firms' compliance responses likely reflect these tradeoffs. Similarly, returns around the rule's announcement and implementation provide evidence on the net costs or benefits to OTCBB firms. An analysis of market liquidity provides evidence on an important source of those costs and benefits and, hence, aids our interpretations of the compliance and return results.

We begin by considering how different groups of firms are affected by the eligibility rule. "Already Compliant" firms were already filing with the SEC and, hence, were not directly affected by the eligibility rule. This group should only be affected if disclosure regulation results in externalities. Among the firms that previously did not file with the SEC, there are likely to be firms for which compliance is too costly. These "Noncompliant" firms are expected to be removed from the OTCBB and to trade in the Pink Sheets. Finally, there may be firms that adopt SEC disclosures for the first time. These "Newly Compliant" firms could have voluntarily filed with the SEC before the rule change, if it had been beneficial to them. The fact that these firms previously did not file with the SEC suggests that even for these firms the costs of SEC disclosures exceed the benefits. Trading in the OTCBB with SEC disclosures is likely to be their next-best alternative and preferred to trading in the Pink Sheets without such disclosures, which is what compels these firms to comply. Thus, we expect three main groups to emerge in response to the eligibility rule. ${ }^{8}$

8 Firms could also go private or "list up" to the NASDAQ, NYSE or AMEX. We find that such responses are rare. Fewer than 90 firms went private or listed up between introduction of the eligibility rule and the phase-in 
Important costs and benefits of disclosure include liquidity, cost of capital, access to financing, agency costs, and proprietary costs. The disclosure literature suggests firm size, ownership structure, financing needs, firm profitability, and industry membership as proxies for these costs and benefits (e.g., Lang and Lundholm, 1993 and 2000; Healy and Palepu, 2001). We expect that these factors also determine the net costs or benefits of SEC disclosure requirements to OTCBB firms and, hence, should explain firms' compliance responses to the eligibility rule. Specifically, we expect Noncompliant firms to be smaller, have more concentrated ownership, lower financing needs, and to differ in profitability. The latter effect is difficult to sign and depends on the importance of agency costs and proprietary costs considerations (Healy and Palepu, 2001; Leuz, 2004).

Next, we turn to our predictions for the stock return tests. Assuming that the market anticipates the economic consequences of the eligibility rule, returns around the key news events announcing the rule provide an initial summary measure of the costs and benefits to firms. Returns around the rule's implementation dates provide an updated measure of the net costs or benefits at a time when the remaining uncertainty about firms' compliance is resolved.

Already Compliant firms should not exhibit abnormal returns in the absence of externalities. Thus, positive or negative returns likely reflect externalities from the imposition of SEC disclosure regulation on previously unregulated firms. We expect Noncompliant firms to be adversely affected by the eligibility rule. Even though noncompliance is their preferred disclosure strategy, these firms are forced into the Pink Sheets, which at the time were generally less reputable and did not offer electronic quotations or price transparency through a web portal 
(see Appendix). Newly Compliant firms are also forced to adopt their second-best alternative, as their disclosure strategy prior to the rule suggests that they preferred to trade in the OTCBB without SEC disclosures. Thus, we expect these firms to be negatively affected as well. If there are positive externalities from the rule change that accrue to all firms (e.g., informational spillovers), they should counteract the described adverse effects for Noncompliant and Newly Compliant firms. But as both groups are still forced into their second-best alternative, we expect them to exhibit lower returns than the Already Compliant firms.

Finally, we form predictions for the market liquidity tests. As Noncompliant firms are forced into a less recognized and less transparent market, they are expected to exhibit lower liquidity. In contrast, Newly Compliant firms substantially increase their disclosures. Prior studies suggest that increased disclosure reduces information asymmetries and increases market liquidity (e.g., Welker, 1995; Leuz and Verrecchia, 2000). Thus, we expect Newly Compliant firms to experience significant increases in liquidity. Market liquidity for Already Compliant firms should be unchanged, unless externalities manifest in positive liquidity changes. For instance, an enhanced OTCBB reputation can increase investors' willingness to trade in this market. Similarly, increased disclosure by Newly Compliant firms can curb private information acquisition for all firms in the market and, hence, result in liquidity spillovers (Admati and Pfleiderer, 2000). Alternatively, firms increasing their disclosure could attract investors away from Already Compliant firms not changing their disclosure, resulting in a negative externality (Fishman and Hagerty, 1989). Whether externalities are positive or negative is ultimately an empirical issue. However, irrespective of the sign and magnitude of the externalities, we expect Newly Compliant firms to exhibit the most favorable change in liquidity due to their increased commitment to disclosure. Noncompliant firms should exhibit the least favorable change. 


\section{Evidence on firms' compliance responses}

\subsection{Sample formation and key compliance samples}

Table 1 provides details on the formation of our sample of OTCBB firms. As of January 4, 1999, there were 6,513 securities quoted on the OTCBB. These securities included multiple issues, as well as warrants, units, preferred stock, and foreign securities, all of which were dropped, leaving a sample of 5,813 domestic common stock issues. Of these issues, 335 firms delisted prior to the phase-in date because they were inactive, had no active market maker, were acquired, or went bankrupt. Another 76 firms listed up to the NASDAQ, AMEX, or NYSE during this period and five went private. These delistings left a sample of 5,402 firms listed on the OTCBB that were subject to the eligibility rule phase-in schedule.

The first column of Table 2 reports statistics for the phase-in of the eligibility rule. Only $31.5 \%$ of the firms reviewed passed the initial compliance test. The remaining $68.5 \%$ failed the initial test and had an "E" added to the end of their ticker symbol. Between the initial compliance test and the phase-in date, 556 firms (10.3\%) became compliant, had the "E" removed from their ticker symbol, and continued to trade on the OTCBB. The majority of firms $(58.2 \%)$ were removed from the OTCBB one day after the phase-in date due to noncompliance with the eligibility rule. Upon delisting, most of these firms moved to the Pink Sheets of the National Quotations Bureau. In fact, the Pink Sheets doubled its number of quoted securities from around 3,000 to more than 6,000 due to the delistings from the OTCBB.

The remaining columns of Table 2 identify the key subsamples used in our primary tests. Newly Compliant firms (826 firms) include all non-SEC-filers in 1998 that adopted SEC disclosure requirements because of the eligibility rule. This group consists of 341 firms that adopted SEC filing prior to the phase-in period, 379 firms that failed the initial compliance test 
but became compliant prior to the phase-in date, and 106 firms that failed to comply prior to the phase-in date, but filed with the SEC within the next two months and hence were reinstated to the OTCBB. We view these firms as late adopters. Noncompliant firms $(2,677)$ did not file with the SEC in 1998 and were removed from the OTCBB when they did not comply with the eligibility rule. ${ }^{9}$ Already Compliant firms $(1,360)$ are issuers that were already filing with the SEC in 1998 and passed the initial compliance test. Finally, firms filing with the SEC in 1998 that did not initially pass the compliance test are either Delinquent firms, which became current in their filings only after failing the initial compliance test, or Terminated filing firms, which stopped filing with the SEC at some point in 1999 and were removed as noncompliant. We delete these firms from our tests because they are likely to be in financial distress and do not fit well in any of the other groups. ${ }^{10}$

Notably, Table 2 shows that only $24 \%$ of the 3,503 non-SEC-filers in 1998 complied with the eligibility rule and remained on the OTCBB, whereas $76 \%$ of these firms moved to the Pink Sheets. These findings are consistent with our expectations. For the majority of firms, the costs of SEC disclosures appear to exceed the benefits, before and after the eligibility rule.

\subsection{Compliance and firm characteristics}

In this section, we examine firm characteristics for SEC filers and non-SEC-filers in 1998 and for Newly Compliant and Noncompliant firms. We use the firm's share price, market value

9 There were almost 200 firms in this group that adopted SEC filing at some point beyond the two-month cut-off and rejoined the OTCBB. Because of the length of time that elapsed after the phase-in date, these firms likely adopted SEC filing for reasons other than the eligibility rule. Note that including these firms in this subsample works against our hypotheses.

10 The results for the Delinquent filers tend to mirror those of the Newly Compliant firms and results for Terminated filers are similar to those of Noncompliant firms. 
of equity, and book value of total assets as alternative measures of firm size. ${ }^{11}$ The number of owners of record is used as proxy for the firm's ownership structure. Alternative measures, such as the percentage of closely-held shares, are only available for a few sample firms. We compute the ratio of property, plant, and equipment to total assets as a measure of capital intensity. Financial leverage is measured as the ratio of long-term debt to total assets. Both capital intensity and financial leverage are meant to capture outside financing needs. Return on assets is used as a proxy for firm profitability and measured as net income over total assets. As we do not have lagged total assets, this variable may suffer from small-denominator problems. Therefore, we also determine the fraction of profitable firms; i.e., firms with positive net income. In addition, we report the percentage of banks and insurance companies in each group, as they are in regulated industries and have to provide financial information to their regulatory agencies.

We obtain financial statement and ownership data from the Global Access SEC database, Mergent's FIS Online database (previously owned by Moody’s Investor Service), and Knobias, an information repository for OTC security research launched in 1999. The databases rely on firms' financial reports, either obtained directly from the firms or from their SEC filings. Of the 5,402 firms in our sample, we have some financial data for 1,991 firms from Global Access, 1,360 firms from Mergent, and 524 firms from Knobias. In addition, we hand collect data from SEC filings for 1,003 firms with missing observations. We combine the datasets to increase data availability and we delete $1 \%$ of the extreme observations on either side of the distribution (except for naturally-bounded variables). All financial and ownership data is measured as of the

11 We have discovered that early in the Datastream data series market values are often incorrect because the series begin with an incorrect number of total shares outstanding. To mitigate this error, we compute shares outstanding as of the last day the firm is listed on Datastream and multiply this figure by the price on a given date to get the market value. As price series are split-adjusted, this adjustment should provide a reasonable approximation of market value for any given date. Results are very similar using the unadjusted market values, but the levels of the market values were much lower. 
fiscal year end between July 1, 1998 and June 30, 1999, and hence prior to the phase-in of the eligibility rule. ${ }^{12}$

Table 3 presents means and medians for various firm characteristics of SEC filers, non-SECfilers, Newly Compliant firms, and Noncompliant firms. As expected, data availability is an issue for non-SEC-filers, particularly for Noncompliant firms. This problem implies that our results likely understate the differences in firm characteristics if the hypothesized factors drive firms' compliance choices. That is, we are less likely to obtain data for firms that are smaller, have more concentrated ownership, and low financing needs. For these reasons, our tests should be interpreted cautiously and be viewed primarily as an attempt to provide some descriptive evidence for the groups used in the subsequent analyses.

Table 3, Panel A, shows that SEC filers are significantly larger, more capital intensive, more highly leveraged, and more profitable than non-SEC-filers. They also have more owners of record, which is not surprising given that Section 12(g) of the Exchange Act requires firms to file with the SEC if they have more than 500 owners of record. ${ }^{13}$ Table 3, Panel A, also reports significant differences among Newly Compliant and Noncompliant firms. The former group exhibits higher market values, lower capital intensity and lower profitability. In addition, banks and insurance companies become compliant and remain on the OTCBB more frequently.

We analyze firms' compliance choices in probit models. The results are reported in Panel B of Table 3. To control for industry and timing effects, we include a bank and insurance indicator

12 For a small number of firms, we have to use financial data (3\%) and ownership data (14\%) from the previous fiscal year because they are missing for the fiscal year end between July 1, 1998 and June 30, 1999.

13 The fact that $50 \%$ of the SEC filers have fewer than 500 owners of record as reported in Table 3 has several reasons (Loss and Seligman, 2001). First, Section 12(g) has different entry and exit criteria. To discontinue filing, firms must either have fewer than 300 owners or fewer than 500 owners and less than $\$ 10$ million in total assets for 3 consecutive years. Second, Section 15(d) mandates periodic SEC filing (1) in the year after the security offering regardless of the number of owners and (2) for three years after the offering if the firm has more than 300, but fewer than 500 owners. Firms may also voluntarily file with the SEC. 
as well as a variable for the number of months from the approval of the eligibility rule on $1 / 4 / 1999$ to the firm's phase-in date. We begin with share price as a size proxy because this variable is available for the majority of firms. Next, we use market value as size proxy, which is clearly preferable but available for fewer firms. Both proxies are positively associated with the decision to continue on the OTCBB. Subsequently, we introduce proxies for financial leverage and profitability, which further reduces sample size. Both variables are only marginally significant, but firms that are able to raise long-term debt and are less profitable appear to be more likely to comply with the eligibility rule. ${ }^{14}$ Overall, the findings are broadly consistent with our expectations, suggesting that compliance choices reflect firms' costs and benefits of disclosure regulation, but they have to be interpreted cautiously due to the sample selection issue.

\section{Stock return tests}

\subsection{Data and variables}

We obtain our return data from two sources. We collect daily price, dividend, shares outstanding, and share volume data from Thomson Financial Datastream, which follows most of the firms on the OTCBB and, more recently, many Pink Sheet firms. However, Datastream stopped following many of the Noncompliant firms in the months following their removal from the OTCBB and did not cover them again until December 2000. We augment the Datastream dataset using daily volume and price data provided by the Pink Sheets. We split-adjust the Pink Sheet price and volume series using overlapping Datastream prices after December 2000.

14 Using capital intensity instead of financial leverage as proxy for financing needs yields a positive, but insignificant coefficient. We use the profitability indicator rather than return on assets, as the former is more often available and not affected by scaling problems. Using return on assets yields similar results to those reported for the net income indicator. Using ranked right-hand side variables instead of deleting extreme observations yields significant results similar to those reported in Table 3. 
We use daily price and dividend data to compute monthly and weekly buy-and-hold returns. Because of the lack of an OTCBB market index, we construct a market index from all OTCBB firms for which we have data. Similar to Luft et al. (2001), we construct an equally-weighted index, rather than a value-weighted index, because of the difficulty in obtaining total shares outstanding, and hence market values, for OTCBB firms. ${ }^{15}$

We also obtain daily return data from Datastream for NASDAQ Small Cap firms (627 firms), which we use as a benchmark sample for the Already Compliant firms and to control for economy-wide return movements. NASDAQ firms have the same SEC filing requirements and are relatively comparable in firm size. At the end of 1998, the average (median) market capitalization of NASDAQ Small Cap firms was \$21.5 (10.9) million compared to $\$ 8.0$ (8.5) million for Already Compliant OTCBB firms.

5.2 Results for returns around dates of news announcements pertaining to the eligibility rule

First, we examine weekly returns around key news announcements pertaining to the proposal and approval of the eligibility rule. These news announcement returns provide a measure of the market's initial assessment of the net costs or benefits for firms and for the market as a whole. We examine five key event dates. On September 4, 1997, the Wall Street Journal published an article detailing instances of fraud on the OTCBB, attributing part of the problem to lack of SEC disclosure requirements, and hinting at changes (WSJ, 9/4/1997). On December 9, 1997, the NASD Board of Governors announced that SEC filing may be required for the OTCBB and that as many as 3,400 firms could be removed (WSJ, 12/9/1997). On

15 The distribution of daily returns reveals a small number of returns greater than $500 \%$ (less than $0.001 \%$ of the distribution). An investigation of some of these returns suggests that they are likely coding errors on the part of the database. To be conservative, we delete all daily returns over 500\%. In addition, because an equally weighted index is susceptible to outliers, we winsorize the return data at the $99^{\text {th }}$ percentile prior to constructing the index. 
February 13, 1998, the NASD Board of Governors proposed several rule changes and approved the solicitation of comment. After the comment period and internal discussions, the NASD Board approved the proposed rule change on May 7, 1998. The SEC finally announced its approval of the eligibility rule on January 4, 1999. As the event dates are the same for all OTCBB firms, the market return reflects the average market reaction to the eligibility rule and hence is not a suitable benchmark. Instead, we use the return of NASDAQ Small Cap firms.

Columns three and four of Table 4 present weekly returns for NASDAQ Small Cap firms and the OTCBB market as a whole on these news announcement dates. Returns are compounded from three days before the news announcement to one day after. The sample is restricted to firms with data for all five event periods. Except on the first event date, the returns for OTCBB firms are similar and not statistically different from contemporaneous returns of NASDAQ Small Cap firms. The mean cumulative return over all event dates is also similar for both markets. ${ }^{16}$

The next two columns of Table 4 report weekly raw returns for firms filing with the SEC during 1998 and for firms not yet filing with the SEC. SEC filing status is observable to the market at the news announcements and could serve as a signal for how firms will be affected by the proposed eligibility rule. ${ }^{17}$ While SEC filers should be unaffected by the proposed rule change, their returns are not expected to be zero if the market expects externalities from the imposition of disclosure regulation. Non-SEC-filers include firms that will ultimately adopt SEC disclosure requirements and firms that will not. The returns for this group are therefore difficult to interpret as they depend also on the expected fraction of Newly Compliant and Noncompliant

16 One issue with this comparison is that the industry composition of the tech-heavy NASDAQ Small Cap differs from the broad industry composition of the OTCBB. Thus, we also collect returns for the Russell 2000. This index is comprised of 2000 small-cap, non-OTCBB firms and hence provides a broader proxy for the market return unrelated to the eligibility rule. Its cumulative return is similar (6.1\%).

17 We include Delinquent and Terminated filing firms in the SEC filer group because the market may not have known at this point whether these firms would stop filing with the SEC prior to the eligibility rule. 
firms. We find that SEC filers have significantly greater returns than non-SEC-filers on four of the five event dates and cumulatively, suggesting that the market recognizes that a large number of firms in the non-SEC-filer group are adversely affected by the eligibility rule. The cumulative returns of the SEC filers are significantly greater than those of the NASDAQ Small Cap firms, consistent with the market anticipating significant externalities for these firms.

The last three columns of Table 4 report weekly returns for Noncompliant, Newly Compliant, and Already Compliant firms. The market does not know these groups at the time of the news announcements, so the tests hinge on the extent to which the market anticipates firms' ultimate compliance choices. Already Compliant firms exhibit the highest returns among all three groups, consistent with positive externalities from disclosure regulation. The cumulative returns to this group are also significantly greater than the returns of NASDAQ Small Cap firms. The cumulative returns of the Newly Compliant firms are significantly less than those for Already Compliant firms. This finding likely reflects the fact that the eligibility rule eliminated the possibility to trade on the OTCBB without significantly increasing disclosures, forcing these firms to their second-best option. The cumulative returns for Newly Compliant firms are 3.1\% higher than those of Noncompliant firms. These findings are consistent with our hypotheses for the three firm groups and the ordering of their returns. Note that the documented patterns are not consistent with a size effect, as Noncompliant and Newly Compliant firms tend to be smaller than Already Compliant firms. ${ }^{18}$ But we acknowledge that event returns could be affected by differences in trading volume across groups and exchanges, which is a concern in low liquidity

18 Nonetheless, we estimate these results in a regression controlling for firm size. Returns to Already Compliant firms remain significantly greater than returns to Newly Compliant and Noncompliant firms. 
markets. Moreover, significant uncertainty about firms' future compliance choices could attenuate the market response at the news announcement dates.

\subsection{Results for returns around the phase-in date}

Next, we examine market-adjusted returns for months and weeks surrounding the phase-in date to examine stock price changes in response to firms' actual compliance choices. Marketadjusted returns are computed as buy-and-hold firm returns minus buy-and-hold returns from the equally-weighted index of all OTCBB firms. ${ }^{19}$ Table 5 presents market-adjusted returns for the Already Compliant firms, Newly Compliant firms, and Noncompliant firms from four months prior to the phase-in date to three months after. To tie the returns directly to the key phase-in dates, we look at weekly market-adjusted returns within the month of the phase-in date and monthly returns outside this window. With the firm-specific phase-in date defined as event date zero, weekly returns for the phase-in date are computed from day -3 to day +1 . During days -23 to -19 , which we label as the "Announcement" week, the OTCBB posts on its website which firms have not passed the initial compliance test. During days -18 to -14 , the "Effective 'E"' week, firms that have failed the initial compliance tests start trading with an "E" appended to their ticker symbol. As this sequence of events applies only to nonfinancial firms, we eliminate financial firms from these tests. ${ }^{20}$

Noncompliant firms experience significantly negative abnormal returns in the month before the announcement week and for almost every period after the Effective "E" week. From the

19 In contrast to the news announcement tests, we compute market-adjusted returns because phase-in dates are spread out over 12 months, implying that, in any given event month, less than $10 \%$ of the market index is comprised of firms that are phased-in during this month. The remainder of the index includes firms that had earlier or later phase-in dates and firms that were added to the OTCBB after January 4, 1999 (and hence had to comply immediately). Thus, in event time, it is unlikely that any group drives the market index as a whole.

20 For banks and insurance companies, the initial compliance test is 60 calendar days, rather than 30 , prior to the phase-in date. We repeated these tests including banks and insurance companies and found similar results. 
Effective "E" week to three months after the phase-in date, Noncompliant firms have marketadjusted returns of around $-25 \% .{ }^{21}$ These results confirm that there are significant net costs to Noncompliant firms related to their removal from the OTCBB and the introduction of the eligibility rule. ${ }^{22}$ Interestingly, most of the negative returns occur only after these firms fail the initial compliance test. This finding may indicate that the market did not completely anticipate the firms' responses until the initial compliance test. An alternative explanation are price pressures if the demand curve is less than perfectly elastic and hence downward sloping, which is not unlikely in low liquidity markets (e.g., Shleifer, 1986).

For Already Compliant firms, we find significantly positive abnormal returns in the Effective "E" week and the following week, as well as the week after the phase-in week. The returns could reflect positive externalities, although it is not clear why these externalities would arise exactly around the phase-in dates of the Already Compliant firms. Again, price pressures and a downward sloping demand curve provide an alternative explanation for these results.

The phase-in results for Newly Compliant firms as a whole are difficult to interpret because the group combines firms with different compliance strategies. Thus, we further split this group into three subgroups: "Pass" firms that complied prior to the initial compliance test, "Fail-Pass" firms that failed the initial review (receiving an "E" on their ticker symbol) but complied prior to the phase-in date, and "Fail-Fail" firms that did not comply by the phase-in date, left the

21 These market-adjusted returns may be overstated by the use of the OTCBB market index. Given these firms are now trading on the Pink Sheets, a Pink Sheet index would be a more appropriate benchmark. But sufficient data is not available to compute a meaningful market return. Moreover, raw returns for Noncompliant firms are generally negative over this period, consistent with losses in market values.

22 This finding is consistent with negative returns in prior work on delistings (e.g., Sanger and Peterson, 1990). However, in our setting, delistings occur as a consequence of a regulatory change rather than firms becoming bankrupt or violating extant exchange listing requirements. 
OTCBB, but rejoined it after complying within two months (Table 2). The last three columns of Table 5 report market-adjusted returns for this decomposition of the Newly Compliant group.

Fail-Pass firms experience significant negative abnormal returns of $-3.6 \%$ and $-3.1 \%$ in the two weeks after receiving the "E" appended to their ticker symbol, but recover in the weeks after the phase-in date. The Fail-Fail firms experience a significantly positive return in the week the failed compliance test is announced. Then, these firms experience a significant negative return of $-5.9 \%$ during the week prior to the phase-in date, indicating that investors price firms' noncompliance, even if it is temporary. Subsequently, these firms do not have significant abnormal returns until they comply and rejoin the OTCBB. As before, these findings can reflect residual uncertainty about the compliance path or, alternatively, prices pressures.

Overall, the phase-in return results are consistent with firms' compliance choices. This section suggests that market prices reflect costs and benefits to firms conditional on whether they comply with the imposed SEC disclosure requirements. While some of the benefits and costs are priced at the announcements leading up to the adoption of the eligibility rule, there are still significant returns in the weeks before the firm-specific phase-in date. This finding suggests that there exists residual uncertainty about firms' compliance choices until the actual phase-in date, but it may also reflect the effects of a downward sloping demand curve in thinly traded markets.

\section{Tests for changes in liquidity measures}

\subsection{Data and variables}

We examine three different proxies for liquidity and trading activity around the introduction the eligibility rule to obtain a fairly comprehensive picture of liquidity changes. First, we analyze the percentage bid-ask spread, computed as the difference between the bid price and the ask price, divided by the midpoint. Second, we use monthly share turnover, computed as 
monthly share volume divided by average total shares outstanding. ${ }^{23}$ Finally, we examine the percentage of days traded during the month, calculated as the number of days in a month that a firm has nonzero volume divided by the number of trading days in the month, which may be a better proxy than share turnover in low-liquidity markets such as the OTCBB.

We obtain data on our liquidity measures from multiple sources. First, the Pink Sheets kindly provided concurrent closing bid and ask prices for two three-month intervals for most of our sample firms. We obtain bid and ask prices for NASDAQ Small Cap firms from the Trade and Quote (TAQ) database. As in the case of the return data, we collect daily volume, shares outstanding, and price data from Datastream, augmented with daily volume and price data provided by the Pink Sheets.

\subsection{Results for long-term shifts in liquidity}

We first examine whether there are any permanent shifts in liquidity measures around the introduction of the eligibility rule. For percentage bid-ask spread, we compare the average spread in three-month intervals before and after the phase-in period (October - December 1998 and 2000, respectively). For share turnover and percentage of days traded, we compare monthly averages for six-month periods before and after the phase-in (December 1998 - May 1999 and December 2000 - May 2001, respectively). We use the same calendar months before and after to ensure that the results are not affected by seasonal differences. This approach uses each firm as its own control and also omits any abnormal and temporary liquidity effects during the phase-

23 One problem in measuring turnover is that the beginning number of shares outstanding is often unreliable earlier in the data series. We therefore adjust shares outstanding as described in footnote 11 . To further mitigate the problem, we eliminate firms with market values below $\$ 100,000$, as they are likely to result from an incorrect number of shares outstanding, and winsorize monthly share turnover at the $95^{\text {th }}$ percentile to remove outliers, resulting from a small denominator. As a robustness check, we examine median monthly turnover and compute the log of monthly share volume without scaling by market value. In both cases, the results are very similar to those reported in Table 6. 
in period. We restrict the test to firms with at least one observation in each three-month (sixmonth) period to ensure the liquidity patterns are not driven by changes in the sample composition, e.g., attrition of sample firms caused by the eligibility rule.

We perform this test on Already Compliant, Newly Compliant, and Noncompliant firms. We benchmark our results with the sample of NASDAQ Small Cap firms. We test for shifts in the liquidity measures with the following regression:

$$
\begin{gathered}
\text { Avg. Liquidity Measure } \text { L }_{i}=\beta_{1} D N O N_{i}+\beta_{2} D_{N O N_{i}} * D P O S T+\beta_{3} D N E W_{i}+\beta_{4} D N E W_{i} * D P O S T+ \\
\beta_{5} D D_{L}+\beta_{6} D_{i} A L R_{i} * D P O S T+\beta_{7} D N Q S C_{i}+\beta_{8} D N Q S C_{i} * D P O S T+\varepsilon_{i t}
\end{gathered}
$$

where Avg. Liquidity Measure $_{i}=$ Three-month average of percentage spread, six-month average value of monthly share turnover, or six-month average value of percentage of days traded in the month for firm $\mathrm{i}$; $D N O N_{i}=1$ if firm i is a Noncompliant firm and 0 otherwise; $D N E W_{i}=1$ if firm i is a Newly Compliant firm and 0 otherwise; $D A L R_{i}=1$ if firm i is an Already Compliant firm and 0 otherwise; $D N Q S C_{i}=1$ if firm i is a NASDAQ Small Cap firm and 0 otherwise; and DPOST $=1$ if the average liquidity measure is from after the phase-in of the eligibility rule and 0 if the measure is from before.

Omitting the intercept, this specification identifies each group separately and the coefficients on the firm indicator variables ( $D N O N, D N E W$, and $D A L R$ ) represent the group's average level of the liquidity measure before the phase-in period. The interaction effect of each firm group indicator with the DPOST indicator variable picks up long-term shifts in the liquidity measure between the pre- and the post-phase-in period. To ensure that market-wide movements do not explain the changes, we perform F-tests for differences in the coefficients across groups.

Prior to the eligibility rule, Noncompliant (Already Compliant) firms exhibit the lowest (highest) liquidity levels, as we expect. ${ }^{24}$ The coefficient on the incremental level of liquidity in 2000/1 for Noncompliant firms (DNON*DPOST) is significantly positive in the bid-ask spread regression, and significantly negative in the turnover and percent of days traded regressions. The

24 Due to the low stock prices of many OTCBB firms, the magnitudes of the mean spreads are quite large. We also examine median spreads and find smaller magnitudes (e.g. 0.415 in 1999 for Noncompliant firms vs. a mean of 0.606). All of the results in Table 6 are also statistically significant using medians. 
F-tests indicate that these changes in liquidity for the Noncompliant firms are significantly different from the changes for the other groups. Thus, Noncompliant firms exhibit significantly lower liquidity across all measures after the phase-in period. Moreover, the shifts in liquidity are economically significant; the incremental coefficients indicate a $12 \%$ increase in the percentage spread and an over 50\% decline in share turnover. These findings suggest that the imposition of SEC disclosures has significant costs to Noncompliant firms, forcing them into a less liquid and less recognized marketplace.

As expected, Newly Compliant firms experience substantial improvements in liquidity. The coefficient on the incremental level of liquidity in 2000/1 (DNEW*DPOST) is significantly negative for the percentage spread and significantly positive for the trading proxies. Moreover, the magnitudes of the changes are larger than for the other groups. F-tests show that prior to the eligibility rule, Newly Compliant firms have significantly higher spreads and fewer days traded than Already Compliant firms. These differences become insignificant after the phase-in period. Thus, Newly Compliant firms not only experience improvements in liquidity after adopting SEC disclosures, but also achieve approximately the same level of liquidity as Already Compliant firms. The latter finding suggests that differences in firms' disclosures were a primary reason for the liquidity differences between the two firm groups prior to the eligibility rule. ${ }^{25}$

Finally, the coefficient on the incremental level of liquidity in 2000/1 for Already Compliant firms (DALR*DPOST) is significantly negative for the bid-ask spread, significantly positive for share turnover, but insignificant in the days traded regression. These results are consistent with the return findings, suggesting liquidity improvements as a source of the positive externalities.

25 Although this result does not hold for share turnover, the log of monthly share volume exhibits the pattern as the other two liquidity proxies. Thus, the turnover pattern could be related to the difficulty of obtaining reliable shares outstanding estimates for these firms. See footnote 11. 
Supporting this argument, NASDAQ Small Cap firms exhibit significantly higher spreads and lower turnover in 2000/1 compared to 1998/9. Thus, the liquidity improvements found for Already Compliant firms do not reflect time trends or economy-wide movements in liquidity.

Although each firm serves as its own control, we also estimate these regressions with additional controls for shifts in firm size (market value), shifts in return volatility (standard deviation of monthly returns), the phase-in month, and regulated industries (banks and insurance companies). Note that the inclusion of the first two controls is potentially problematic because changes in size and volatility could be additional consequences of the firm's compliance decision, rather than exogenous determinants of the changes in liquidity. Nonetheless, we find that results are robust to these additional controls, with the only notable difference being that the increase in turnover for Already Compliant firms is only weakly significant $(p$-value $=0.14)$. All other changes remain significant with the inclusion of the controls.

Overall, the results suggest that liquidity is an important mechanism through which disclosure regulation affects firms.

\subsection{Sensitivity analyses}

We examine changes in liquidity measures in the months surrounding the firm-specific phase-in date. This analysis addresses the concern that the previous results are driven by unobserved differences across the groups and allows us to tie the long-term shifts in liquidity to the eligibility rule. We examine monthly changes in turnover and percent of days traded starting four months before the phase-in date up to three months after. We do not have bid-ask spread data for these tests.

We find that Noncompliant firms exhibit a significant increase in trading activity in the two months prior to the phase-in date. This increased activity likely reflects investor rebalancing in 
anticipation of the firms' pending noncompliance, consistent with the abnormal return results documented in Table 5. Immediately after removal from the OTCBB, Noncompliant firms experience a significant decline in trading activity, consistent with our expectations and previous results. Newly Compliant firms also exhibit a significant increase in trading activity two months prior to the phase-in date that peaks in the month of the phase-in, consistent with the return results and reflecting trading based on firms' compliance choices. After the phase-in date, liquidity slowly declines to roughly those elevated levels observed in Table 6. Thus, while not all liquidity increases are sustained, the long-term shifts documented in Table 6 appear to occur around the phase-in date. For Already Compliant firms, there is a significant increase in trading activity two months before the phase-in date that persists through the next five months. These liquidity improvements are not fully sustained in the long-run, suggesting that some of the increases around the phase-in reflect the price pressures documented in Table 5. Overall, these results tie the liquidity changes to the eligibility rule and provide evidence consistent with firms' compliance choices and associated stock returns around the firm-specific phase-in dates.

Next, we examine whether certain types of firms drive the results. First, we eliminate banks and insurance firms from the sample because their phase-in schedules are different and they have special reporting obligations with their regulatory bodies. We find that restricting the samples to non-financial firms produces almost identical results. Second, we eliminate firms in bankruptcy proceedings, as indicated by a "Q" at the end of their ticker symbol. These firms are often delisted from one of the major exchanges and have characteristics much different than the average OTCBB firm. Again, we find essentially the same results as those reported in Tables 46. 
Finally, we address the issue that the Already Compliant group may contain some firms that voluntarily adopted SEC filing prior to the introduction of the eligibility rule. It is possible that the change from voluntary to mandatory filing for those firms, rather than externalities, drives the results for the Already Compliant firms. However, it is not obvious what changes for voluntary firms as disclosure requirements, SEC enforcement, and legal liability are essentially the same for voluntary and mandatory filers (see Appendix). We classify firms with 500 or more (fewer than 300) owners of record in 1998 as mandatory (voluntary) filers based on Section 12(g) filing and termination rules. Firms with between 300 and 500 owners can discontinue filing only if it is neither the year of the IPO nor total assets exceeded \$10 million for the last three fiscal year ends. As we do not have data on three years of total assets prior to 1998, we cannot definitely determine whether filing is voluntary or not. Therefore, we classify these firms once as voluntary and once as mandatory, and compare the findings.

Irrespective of the classification of this middle group, we find similar return results for voluntary and mandatory firms around the announcement and phase-in dates. We also find that both voluntary and mandatory filers exhibit similar decreases in the spreads and that their magnitudes are very close to those reported in Table 6 , albeit at lower significance levels due to the reduced sample size. For share turnover, mandatory filers exhibit smaller increases than voluntary firms. However, the magnitude of the incremental changes for the mandatory firms is still comparable to those reported in Table 6 ( 0.26 and 0.12 depending on the assignment of firms with 300 to 499 owners). In summary, our evidence for the Already Compliant group does not seem to be driven by voluntary filers alone and continues to be consistent with the existence of positive externalities of disclosure regulation. 


\section{Conclusions}

This paper examines the economic consequences of SEC disclosure regulation. We exploit a recent regulatory change mandating firms on the OTC Bulletin Board to comply with the reporting requirements under the Securities Exchange Act of 1934. Prior to 1999, firms could be quoted on the OTCBB without filing with the SEC. The eligibility rule eliminated this possibility and forced over 3,500 firms that were not previously filing with the SEC to either make the required disclosures or move to the Pink Sheets. Firms already filing with the SEC were not affected by the rule. We use this regulatory event, and the three groups created by it, to document firm-specific costs and benefits, as well as externalities, of disclosure regulation.

The eligibility rule had rather dramatic consequences for the composition of the OTCBB. Almost $75 \%$ of the firms not previously filing with the SEC were removed from the market during the rule's phase-in period and forced into the Pink Sheets, where they are not subject to SEC disclosure requirements and associated enforcement. Thus, for the majority of OTCBB firms, the costs of SEC disclosure regulation outweigh the benefits. Consistent with this interpretation, we find that Noncompliant firms are smaller and less leveraged. These results suggest that an important consequence of mandatory SEC disclosures is to push smaller firms with lower outside financing needs into a less regulated market, rather than to compel them to more disclosure. This evidence is consistent with "crowding out" effects documented in prior studies (Stigler, 1964; Jarrell, 1981) and shows that it is important to consider firms' responses (or avoidance strategies) to the imposition of disclosure regulation. In this regard, the Pink Sheets may have played an important role. Its existence and possibly anticipated improvements of this market likely prevented more firms from going private but at the same time may have limited the number of firms that were compelled to adopt SEC disclosures by the eligibility rule. 
Market reactions to firms' compliance responses are consistent with their prior disclosure strategies and their responses to the eligibility rule. Stock returns around the key announcement and phase-in dates of the eligibility rule indicate significant costs to Noncompliant and Newly Compliant firms from the imposition of SEC disclosures. In contrast, Already Compliant firms exhibit positive announcement returns, consistent with the existence of positive externalities.

The liquidity analysis corroborates the return results. Across all measures, firms that previously did not file with the SEC but were compelled to adopt SEC disclosures exhibit substantial increases in liquidity. In contrast, firms not complying with the eligibility rule and forced off the OTCBB experience permanent decreases in liquidity. We also find increases in liquidity for the Already Compliant firms, suggesting improved liquidity as a possible source of externalities, perhaps due to better market reputation. While these results indicate that liquidity is an important mechanism through which disclosure regulation affects firms, we acknowledge that it is by no means the only one. Finally, we emphasize that our revealed preference approach limits the extent to which our findings can be extrapolated to settings in which firms do not have much of a choice about whether to comply with newly imposed regulation. In our setting, firms' compliance choices can be exploited to infer firm-specific costs and benefits of SEC disclosure regulation and to show the consistency across firms' choices, returns and liquidity changes. 


\section{References}

Admati, A., Pfleiderer, P., 2000. Forcing firms to talk: Financial disclosure regulation and externalities. The Review of Financial Studies 13, 479-519.

Amihud, Y., Mendelson, H., 1986. Asset pricing and the bid-ask spread. Journal of Financial Economics 17, 223-249.

Benston, G., 1969. The value of the SEC's accounting disclosure requirements. The Accounting Review 54, 515-532.

Benston, G., 1973. Required disclosure and the stock market: An evaluation of the Securities Exchange Act of 1934. The American Economic Review 63, 132-155.

Brennan, M., Chordia, T., Subrahmanyam, A., 1998. Alternative factor specifications, security characteristics, and the cross-section of expected stock returns. Journal of Financial Economics 49, 345-374.

Coffee, J., 1984. Market failure and the economic case for a mandatory disclosure system. Virginia Law Review 70, 717-753.

Chordia, T., Roll, R., Subrahmanyam, A., 2001. Trading activity and expected stock returns. Journal of Financial Economics 59, 3-32.

Dye, R., 1990. Mandatory versus voluntary disclosures: The cases of financial and real externalities. The Accounting Review 65, 1-24.

Easterbrook, F., Fischel, D., 1984. Mandatory disclosure and the protection of investors. Virginia Law Review 70, 669-715.

Fields, T., Lys, T., Vincent, L., 2001. Empirical research on accounting choice. Journal of Accounting and Economics 31, 255-308.

Fishman, M., Hagerty, K., 1989. Disclosure decisions by firms and the competition for price efficiency. Journal of Finance 44, 633-646.

Friend, I., Herman, E., 1964. The SEC through a glass darkly. Journal of Business 37, 382-401.

Greenstone, M., Oyer, P., and Vissing-Jorgensen, A., 2003. Mandated disclosure, stock returns, and the 1964 Securities Acts Amendments. Working paper, MIT.

Healy, P., Palepu, K., 2001. Information asymmetry, corporate disclosure, and the capital markets: A review of the empirical disclosure literature. Journal of Accounting and Economics 31, 405-440.

Hirshleifer, J., 1971. The private and social value of information and the reward to incentive activity. The American Economic Review 61, 561-574. 
Huddart, S., Hughes, J., Brunnermeier, M., 1999. Disclosure requirements and stock exchange listing choice in an international context. Journal of Accounting and Economics 26, 237269.

Jarrell, G., 1981. The economic effect of federal regulation of the market for new security issues. Journal of Law and Economics 24, 613-675.

Kothari, S. P., 2001. Capital markets research in accounting. Journal of Accounting and Economics 31, 105-231.

Lang, M., Lundholm, R., 1993. Cross-sectional determinants of analyst ratings of corporate disclosures. Journal of Accounting Research 31, 246-271.

Lang, M., Lundholm, R., 2000. Voluntary disclosure and equity offering: Reducing information asymmetry or hyping the stock? Contemporary Accounting Research 17, 623-62.

Leuz, C., 2004. Proprietary versus Non-Proprietary Disclosures: Evidence from Germany, in: The Economics and Politics of Accounting, C. Leuz, D. Pfaff and A. Hopwood (eds), Oxford University Press, Oxford et al.

Leuz, C., Verrecchia, R., 2000. The economic consequences of increased disclosure. Journal of Accounting Research 38, 91-124.

Levitt, A., 1998. The importance of high quality accounting standards, Accounting Horizons 12, 79-82.

Loss, L., Seligman, J., 2001. Fundamentals of Securities Regulation, $4^{\text {th }}$ edition, Aspen Law \& Business: Gaithersburg, MD.

Luft, C., Levine, L., Larson, S., 2001. Over the counter bulletin board exchange: Market structure, risk and return. Journal of Alternative Investments 4, 33-42.

Sanger, G., Peterson, J., 1990. An empirical analysis of common stock delistings. Journal of Financial and Quantitative Analysis 25, 261-272.

Seligman, J., 1983. The historical need for a mandatory corporate disclosure system. Journal of Corporate Law 9, 1-33.

Shleifer, A., 1986, Do demand curves for stocks slope down? Journal of Finance 41, 579-590.

Sivakumar, K., Waymire, G., Basu, S., 2003, Enforceable accounting rules and income measurement by early 20th century railroads. Journal of Accounting Research 41, 397-445.

Stigler, G., 1964. Public regulation of the securities markets, Journal of Business 37, 117-142.

Sutton, M., 1997. Financial reporting in U.S. capital markets: International dimensions. Accounting Horizons 11, 96-102.

Verrecchia, R., 2001. Essays on disclosure. Journal of Accounting and Economics 32, 91-180. 
Watts, R., Zimmerman, J., 1986. Positive Accounting Theory. Prentice-Hall, Englewood Cliffs, NJ.

Welker, M., 1995. Disclosure Policy, Information Asymmetry, and Liquidity in Equity Markets. Contemporary Accounting Research 11, 801-827. 


\begin{tabular}{|c|c|c|c|c|c|c|c|c|c|c|c|}
\hline \multirow[b]{2}{*}{ Market } & \multirow[b]{2}{*}{ Firms } & \multicolumn{4}{|c|}{ Market Characteristics } & \multicolumn{3}{|c|}{ Disclosure Requirements } & \multicolumn{3}{|c|}{ Enforcement Rules } \\
\hline & & 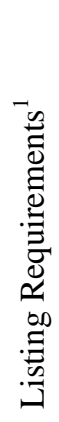 & 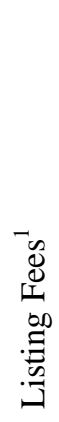 & $\begin{array}{l}\text { ते } \\
\overrightarrow{0} \\
0 \\
0 \\
0 \\
0 \\
0 \\
.0 \\
.0 \\
.0 \\
.0\end{array}$ & 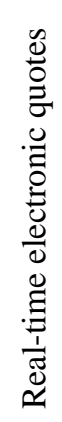 & 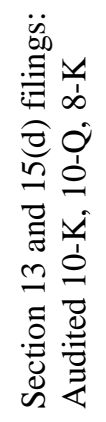 & 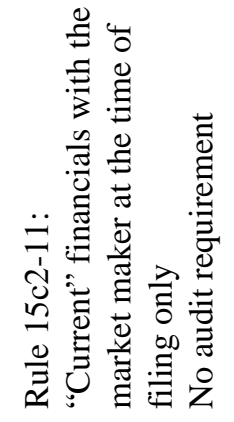 & 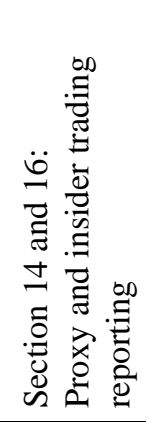 & 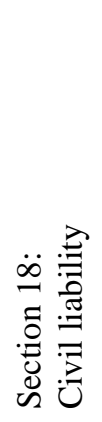 & 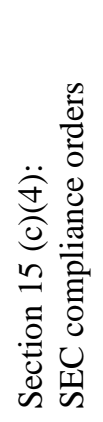 & 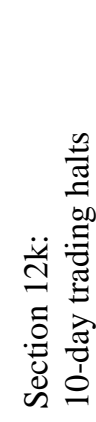 \\
\hline NASDAQ Small Cap & All firms & $\mathrm{Y}$ & $\mathrm{Y}$ & $\mathrm{Y}$ & $\mathrm{Y}$ & $\mathrm{Y}$ & Exempt & $\mathrm{Y}$ & $\mathrm{Y}$ & $\mathrm{Y}$ & $\mathrm{Y}$ \\
\hline $\begin{array}{l}\text { OTCBB } \\
\text { Before 1/4/99 }\end{array}$ & SEC filers ${ }^{3}$ & $\mathrm{~N}$ & $\mathrm{~N}$ & $\mathrm{Y}$ & $\mathrm{Y}$ & $\mathrm{Y}$ & Exempt & $\mathrm{Y}^{3}$ & $\mathrm{Y}$ & $\mathrm{Y}$ & $\mathrm{Y}$ \\
\hline $\begin{array}{l}\text { OTCBB } \\
\text { Before 1/4/99 }\end{array}$ & Non-SEC-filers & $\mathrm{N}$ & $\mathrm{N}$ & $\mathrm{Y}$ & Y & $\mathrm{N}$ & $\mathrm{Y}$ & $\mathrm{N}$ & $\mathrm{N}$ & $\mathrm{N}$ & $\mathrm{Y}$ \\
\hline $\begin{array}{l}\text { OTCBB } \\
\text { After 1/4/99 }\end{array}$ & All firms & $\mathrm{N}$ & $\mathrm{N}$ & $\mathrm{Y}$ & $\mathrm{Y}$ & $\mathrm{Y}$ & Exempt & $\mathrm{N}^{6}$ & $\mathrm{Y}$ & $\mathrm{Y}$ & $\mathrm{Y}$ \\
\hline Pink Sheets & Non SEC filers ${ }^{4}$ & $\mathrm{~N}$ & $\mathrm{~N}$ & $\mathrm{~N}$ & $\mathrm{~N}^{5}$ & $\mathrm{~N}$ & $\mathrm{Y}$ & $\mathrm{N}$ & $\mathrm{N}$ & $\mathrm{N}$ & $\mathrm{Y}$ \\
\hline
\end{tabular}

1 To continue trading on the NASDAQ Small Cap market, a firm must have a minimum bid price of $\$ 1.00$, at least two market makers, at least 300 shareholders, and meet one of the following criteria: $\$ 2.5$ million in shareholders' equity, $\$ 35$ million in market cap, or $\$ 500,000$ in net income from continuing operations. Listing fees for the NASDAQ Small Cap market include a $\$ 10,000$ - $\$ 50,000$ entry fee (based on shares outstanding) and at least $\$ 8,000$ in annual fees.

2 The Pink Sheets have no rules for quotes (they can be two-sided, one-side, or indicative only). On the OTCBB, market makers pay $\$ 6$ per security per month, whereas on the Pink Sheets, market makers face a tiered fee schedule based on the total number of securities quoted. For this reason, it is generally cheaper for market makers to quote large numbers of low-volume stocks on the Pink Sheets than on the OTCBB. In addition, market making on the OTCBB requires a NASDAQ terminal.

3 SEC filers on the OTCBB before 1/4/99 would include Section $12(\mathrm{~g})$ firms, Section $15(\mathrm{~d})$ firms, and voluntary filers. Section $12(\mathrm{~g})$ firms are issuers with more than $\$ 10$ million in total assets and at least 500 registered owners at the fiscal year end. Section 15(d) firms are issuers that registered securities under the 1933 Act (e.g., offered more than $\$ 1$ million in equity). Both Section 12(g) and Section 15(d) firms have to comply with the reporting obligations under the 1934 Act regardless of where they are quoted. Section 15(d) filers, however, are exempted from the proxy and insider trading provisions.

4 Mandatory and voluntary SEC filers on the Pink Sheets face the same disclosure requirements and enforcement rules as SEC filers on the OTCBB (see row 2).

5 The Pink Sheets moved to electronic quotations in September 1999 and launched a web portal supporting quote dissemination to investors in June 2000.

6 Firms above the Section 12(g) limits continue to be subject to the proxy and insider trading provisions as indicated in the second row. 
Table 1

Sample Formation

Number of securities listed on OTCBB as of 1/4/99

- Multiple issues for the same firm

- Foreign firms and firms with only warrants or preferred stock on OTCBB

Number of firms with primary issues listed on OTCBB as of 1/4/99

- Firms delisting from OTCBB prior to phase-in date

Bankruptcies and Liquidations

Mergers and Acquisitions

Gone private

Listed on AMEX/NYSE

Listed on NASDAQ

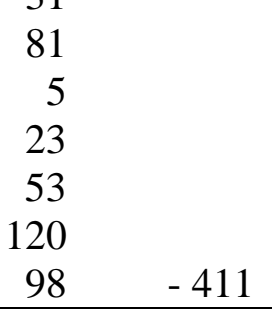

Delisted due to Rule 15c (no active market maker)

5402

Number of firms reviewed by OTCBB at phase-in date

The table provides statistics for the numbers of issuers quoted on the OTC Bulletin Board as of 1/4/1999. The statistics have been compiled from the archived daily lists of additions, deletions, and changes found at www.otcbb.com. 
Table 2

Subsamples of firms based on compliance with eligibility rule

\begin{tabular}{|c|c|c|c|c|c|}
\hline & \multirow[b]{2}{*}{ All Firms } & \multicolumn{2}{|c|}{$\begin{array}{l}\text { Non-SEC-filers in } 1998 \\
(\mathrm{n}=3,503)\end{array}$} & \multicolumn{2}{|c|}{$\begin{array}{l}\text { SEC filers in } 1998 \\
\quad(\mathrm{n}=1,899)\end{array}$} \\
\hline & & $\begin{array}{c}\text { Newly } \\
\text { Compliant }\end{array}$ & $\begin{array}{c}\text { Non- } \\
\text { compliant }\end{array}$ & $\begin{array}{c}\text { Already } \\
\text { Compliant }\end{array}$ & $\begin{array}{l}\text { Delinquent / } \\
\text { Terminated }\end{array}$ \\
\hline Firms that passed initial compliance test & $1701 \quad(31.5 \%)$ & 341 & & 1360 & \\
\hline Firms that became compliant in review period & $556 \quad(10.3 \%)$ & 379 & & & 177 \\
\hline $\begin{array}{l}\text { Firms that failed compliance test at phase-in date } \\
\text { Complied within two months after failing } \\
\text { Never complied or complied after two months }\end{array}$ & $3145(58.2 \%)$ & 106 & 2677 & & $\begin{array}{r}16 \\
346 \\
\end{array}$ \\
\hline Total & 5402 & 826 & 2677 & 1360 & 539 \\
\hline
\end{tabular}

This table provides details on the composition of key subsamples of firms examined in the primary tests. The rows of the table provide phase-in statistics for our sample firms that were quoted on the OTC Bulletin Board and subject to the eligibility rule as of 1/4/1999 (see Table 1). Nonfinancial Issuers were assigned a phase-in date between July 1999 and May 2000 based on the firm's ticker symbol as of 1/4/1999. The phase-in date is the date by which the issuer has to be compliant with the eligibility rule, i.e., has to be current in its filings with the SEC. Issuers were reviewed 30 days prior to this date. Banks and insurance companies were assigned phase-in dates in June 2000 and evaluated 60 days prior to this date. The first row reports the number of firms that passed the initial compliance test. Firms that initially failed, but complied within the 30- (or 60-) day review period are reported the second row. Firms that failed to comply with the eligibility rule as of the phase-in date (third row) were removed from the OTCBB, effective one day after the phase-in date. The columns of the table divide these firms by their 1998 SEC filing status. SEC filers include all firms that filed either a periodic report (any Form 10-K, 10-Q) or a registration statement requiring financial statements during 1998. All firms for which we were unable to find a 1998 filing are classified on non-SEC-filers. Filing data was obtained from the SEC's ftp site. "Newly Compliant" firms consist of non-filers in 1998 that (1) adopted SEC filing prior to the phase-in period, (2) failed the initial compliance test but became compliant prior to the phase-in date, and (3) failed to comply with the eligibility rule prior to the phase-in date but did adopt SEC filing within the next two months and were reinstated to the OTCBB. "Noncompliant" firms include all non-filers in 1998 that did not comply with SEC filing requirements in response to the eligibility rule and hence were dropped to the Pink Sheets. "Already Compliant" firms are issuers that were already filing with the SEC in 1998 and passed the initial compliance test. "Delinquent" ("Terminated") filers include firms filing with the SEC in 1998 that were not current in their filings at the initial compliance test, but became compliant (remained noncompliant) after the test. These firms are dropped from the analyses. 
Table 3

Listing Choices and Firm Characteristics

Panel A: Descriptive Statistics for SEC-Filers vs. Non-SEC-filers and Newly Compliant vs. Noncompliant firms

\begin{tabular}{|c|c|c|c|c|c|c|c|c|c|c|c|c|}
\hline \multirow[b]{2}{*}{ Variable } & \multicolumn{3}{|c|}{ SEC Filers } & \multicolumn{3}{|c|}{ Non-SEC-filers } & \multicolumn{3}{|c|}{ Newly Compliant } & \multicolumn{3}{|c|}{ Noncompliant } \\
\hline & $\mathrm{N}$ & Mean & Median & $\mathrm{N}$ & Mean & Median & $\mathrm{N}$ & Mean & Median & $\mathrm{N}$ & Mean & Median \\
\hline Share price & 1560 & 6.543 & 0.688 & 2553 & $8.790^{* * * *}$ & $0.700^{* * *}$ & 628 & 12.213 & 3.875 & 1925 & $7.673^{* * * *}$ & $0.391^{* * *}$ \\
\hline Market value (000s) & 1252 & 31523.9 & 7712.9 & 1064 & 34188.3 & $6553.9^{* * *}$ & 408 & 61038.2 & 24992.0 & 656 & $17488.9^{\text {*** }}$ & $1196.3^{* * *}$ \\
\hline Total assets $(000 \mathrm{~s})$ & 1777 & 48165.9 & 4332.0 & 773 & $35306.9^{* *}$ & $1043.0^{* * * *}$ & 401 & 41567.1 & 1042.0 & 372 & 28558.7 & 1084.3 \\
\hline Owners of record & 1680 & 944.4 & 500.0 & 208 & $704.0^{* * *}$ & $371.0^{* * * *}$ & 128 & 721.5 & 362.0 & 80 & 676.1 & 389.5 \\
\hline Capital intensity & 1719 & 0.227 & 0.125 & 732 & 0.224 & $0.105^{\text {**** }}$ & 375 & 0.209 & 0.081 & 357 & 0.240 & $0.141^{* *}$ \\
\hline Financial leverage & 1384 & 0.266 & 0.066 & 548 & 0.223 & $0.003^{* * *}$ & 269 & 0.258 & 0.007 & 279 & 0.189 & 0.001 \\
\hline Return on assets & 1743 & -1.201 & -0.169 & 749 & $-1.993^{* * *}$ & $-0.305^{* * *}$ & 392 & -2.249 & -0.377 & 357 & -1.712 & $-0.275^{*}$ \\
\hline Positive net income indicator & 1809 & 0.314 & 0.000 & 890 & $0.266^{* *}$ & $0.000^{* * *}$ & 468 & 0.259 & 0.000 & 422 & 0.275 & 0.000 \\
\hline Bank \& insurance indicator & 1899 & 0.065 & 0.000 & 3503 & $0.131^{* * *}$ & $0.000^{* * *}$ & 826 & 0.275 & 0.000 & 2677 & $0.087^{* * * *}$ & $0.000^{* * * *}$ \\
\hline
\end{tabular}

Panel B: Determinants of Firms' Compliance Choices (Newly Compliant versus Noncompliant firms)

\begin{tabular}{|c|c|c|c|c|c|c|c|c|}
\hline & \multicolumn{2}{|c|}{ Newly Compliant=1 } & \multicolumn{2}{|c|}{ Newly Compliant=1 } & \multicolumn{2}{|c|}{ Newly Compliant=1 } & \multicolumn{2}{|c|}{ Newly Compliant=1 } \\
\hline & Coeff. & $\mathrm{p}$-value & Coeff. & p-value & Coeff. & $\mathrm{p}$-value & Coeff. & p-value \\
\hline Constant & -1.504 & $<0.001$ & -3.958 & 0.001 & -1.155 & $<0.001$ & -2.093 & $<0.001$ \\
\hline Months to phase-in date & 0.061 & $<0.001$ & 0.055 & 0.001 & 0.087 & $<0.001$ & 0.068 & 0.017 \\
\hline Bank \& insurance indicator & 0.397 & $<0.001$ & 0.593 & $<0.001$ & 0.624 & 0.124 & 0.927 & 0.120 \\
\hline Log Size (Share price) & 0.134 & $<0.001$ & - & - & 0.066 & 0.041 & - & - \\
\hline Log Size (Market value) & & & 0.333 & $<0.001$ & - & - & 0.146 & 0.001 \\
\hline Financial leverage & & & & & 0.126 & 0.115 & 0.190 & 0.109 \\
\hline Profitability & & & & & -0.264 & 0.084 & -0.212 & 0.266 \\
\hline Pseudo $\mathrm{R}^{2}$ & & 0.112 & & 0.235 & & 0.051 & & 0.069 \\
\hline $\mathrm{N}$ & & 2429 & & 1040 & & 457 & & 299 \\
\hline
\end{tabular}

$* * *, * *, *$ Significantly different from other group at the $0.01,0.05$ and 0.10 level, respectively, using a two-tailed t-test and Wilcoxon test

The table presents firm characteristics for SEC filers, non-SEC-filers, Newly Compliant and Noncompliant firms. Panel A reports univariate tests for differences in the means and medians. Panel B reports probit models for firms' compliance choices. P-values are based on robust (Huber-White) standard errors. Share price and market value of equity are as of 6/30/1999. To correct for errors in the number of shares outstanding early in the data series, we use the shares outstanding as of the last day with Datastream data and multiply this figure by the split-adjusted price from Datastream or the Pink Sheets. Financial and ownership data are obtained from Global Access' SEC database, Mergent's FIS database, Knobias and SEC filings on EDGAR. We combine the datasets to increase data availability. All financial and ownership data is measured as of the fiscal year end between July 1 , 1998 and June 30, 1999. For a small number of firms, we use financial data (3\%) and owners of record data (10\%) from the previous fiscal year end because the desired year is missing. Capital intensity is measured as the ratio of plant, property and equipment to total assets. Financial leverage is measured as the ratio of long-term debt to total assets. The return of assets is computed as net income over total assets. The indicator for positive net income equals one if net income is greater than zero and equals zero otherwise. The indicator for banks and insurance companies is obtained from the OTCBB's webpage. We delete prices below $\$ 0.01$ and market values below $\$ 100,000$ as they are probably erroneous. We also delete $1 \%$ extreme observations on either side of the distribution, except when the variable is naturally bounded. 
Table 4

Mean Raw Returns around Eligibility Rule Announcement Dates

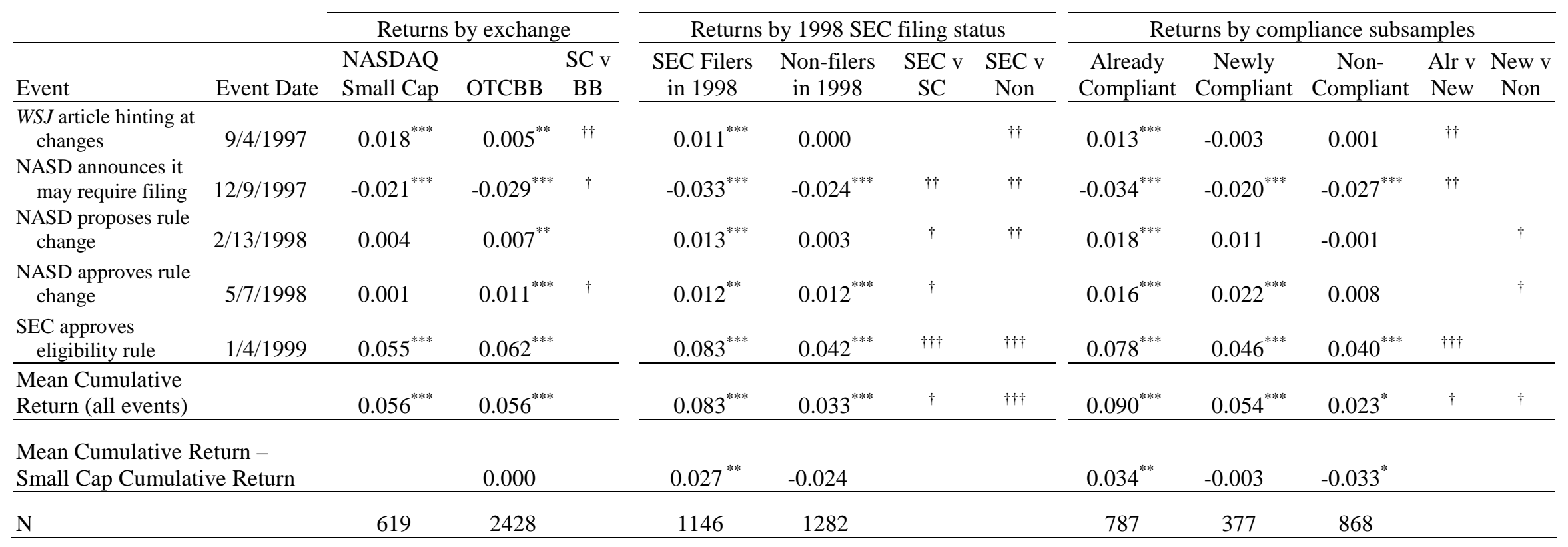

$* * *, * *, *$ Significantly different from zero at the $0.01,0.05,0.10$ level, respectively, using a two-tailed test

$+\dagger,{ }^{\dagger},{ }^{\dagger}$ Significant difference between groups at the $0.01,0.05,0.10$ level, respectively, using a two-tailed test

The table presents 5-day raw returns for key announcements related to the introduction of the eligibility rule. The 5-day buy-and-hold returns are compounded from day -3 to day +1 around the event date given in column 2 (excluding holidays). The second-to-last row reports the mean cumulative return for the subsample minus the mean cumulative return for the NASDAQ Small Cap. $\mathrm{N}$ is the number of firms in the subsample. Column 3 reports average 5-day return for a sample of firms listed on the NASDAQ Small Cap Exchange. Column 4 provides average 5-day returns for all OTC Bulletin Board firms for which we have price data for all five dates. The "SC v BB" column indicates whether these returns are significantly different from each other. The next two columns report the announcement returns for firms that filed with the SEC during 1998 and firms that did not file with the SEC during 1998 . See Table 2 for more details on the SEC filing. The "SEC v. SC" ("SEC v. Non") column indicates whether the returns of the SEC filers in 1998 are significantly different from the NASDAQ Small Cap firms (Non-SEC-filers in 1998). The next three columns report announcement returns for Already Compliant firms, which are issuers that were already filing with the SEC in 1998 and which passed the initial compliance test; Newly Compliant firms, which include all non-SEC-filers in 1998 that adopt SEC filing because of the eligibility rule; and Noncompliant firms, which include all non-SEC-filers in 1998 that did not comply with SEC filing requirements and hence were dropped to the Pink Sheets. The "Alr v. New" ("New v. Non") column indicates whether the returns for Newly Compliant group are significantly different from the returns for the Already Compliant (Noncompliant) group. 
Table 5

Mean Monthly and Weekly Market-Adjusted Returns around Phase-in Dates

\begin{tabular}{|c|c|c|c|c|c|c|c|}
\hline \multirow{2}{*}{\multicolumn{2}{|c|}{$\begin{array}{l}\text { Trading Days } \\
\text { relative to phase-in }\end{array}$}} & \multirow[b]{2}{*}{$\begin{array}{c}\text { Already } \\
\text { Compliant }\end{array}$} & \multirow[b]{2}{*}{$\begin{array}{c}\text { Newly } \\
\text { Compliant }\end{array}$} & \multirow[b]{2}{*}{$\begin{array}{c}\text { Non- } \\
\text { Compliant }\end{array}$} & \multicolumn{3}{|c|}{ Newly Compliant Firms } \\
\hline & & & & & Pass & Fail-Pass & Fail-Fail \\
\hline & $(-86,-66)$ & 0.019 & 0.025 & -0.009 & 0.002 & 0.043 & 0.021 \\
\hline & $(-65,-45)$ & -0.018 & 0.025 & -0.012 & 0.027 & 0.034 & -0.004 \\
\hline & $(-44,-24)$ & 0.014 & 0.023 & $-0.037^{* * *}$ & -0.021 & 0.029 & 0.096 \\
\hline \multicolumn{2}{|c|}{ Announcement $(-23,-19)$} & 0.005 & $0.017^{*}$ & $-0.008^{*}$ & 0.017 & 0.005 & $0.047^{* *}$ \\
\hline \multirow[t]{3}{*}{ Effective "E" } & $(-18,-14)$ & $0.012^{* *}$ & 0.006 & -0.007 & 0.010 & 0.005 & -0.003 \\
\hline & $(-13,-9)$ & $0.013^{* *}$ & $-0.020^{* *}$ & $-0.032^{* * *}$ & -0.001 & $-0.036^{* * *}$ & -0.014 \\
\hline & $(-8,-4)$ & 0.003 & $-0.017^{* *}$ & $-0.052^{* * *}$ & 0.021 & $-0.031^{* *}$ & $-0.059^{* * * *}$ \\
\hline \multirow[t]{7}{*}{ Phase-in date } & $(-3,+1)$ & -0.006 & 0.008 & $-0.020^{* * *}$ & -0.003 & 0.013 & 0.019 \\
\hline & $(+2,+6)$ & $0.016^{* * *}$ & 0.001 & $-0.023^{* * * *}$ & 0.000 & 0.015 & -0.033 \\
\hline & $(+7,+11)$ & 0.010 & $0.026^{* * *}$ & $-0.021^{* * *}$ & -0.013 & $0.063^{* * *}$ & 0.007 \\
\hline & $(+12,+16)$ & -0.001 & $0.029^{* * *}$ & -0.003 & 0.013 & $0.042^{* * *}$ & 0.029 \\
\hline & $(+17,+37)$ & -0.006 & -0.011 & $-0.084^{* * *}$ & -0.047 & -0.018 & 0.083 \\
\hline & $(+38,+58)$ & -0.017 & 0.004 & $-0.033^{* *}$ & $-0.123^{* * *}$ & 0.045 & $0.146^{* *}$ \\
\hline & $(+59,+79)$ & -0.019 & $-0.058^{* *}$ & -0.013 & -0.036 & $-0.070^{* * *}$ & -0.070 \\
\hline $\mathrm{N}$ & & 1221 & 562 & 2136 & 202 & 261 & 99 \\
\hline
\end{tabular}

$* * *, * *, *$ Significantly different from zero at the $0.01,0.05,0.10$ level, respectively, using a two-tailed test

This table presents the mean market-adjusted returns for months and weeks before, during, and after the phase-in of the eligibility rule. Day 0 is the phase-in date for each firm. Market-adjusted returns are buy-and-hold firm returns minus buy-and-hold returns on an equally-weighted market index of all firms in the OTCBB. The Announcement week is when the OTCBB posts whether the firms have passed the initial compliance test and the Effective "E" week is when the firms that have not yet complied begin to trade with an "E" appended to their ticker symbols. The sample is comprised of Already Compliant firms, which are issuers that were already filing with the SEC in 1998 and which passed the initial compliance test; Newly Compliant firms, which include all non-SEC-filers in 1998 that adopt SEC filing because of the eligibility rule; and Noncompliant firms, which include all non-SEC-filers in 1998 that did not comply with SEC filing requirements and hence were dropped to the Pink Sheets. The Newly Compliant group is further broken down into Pass firms, which adopted SEC filing prior to the phase-in period, FailPass firms, which failed the initial compliance test but became compliant prior to the phase-in date, and Fail-Fail firms, which failed to comply with the eligibility rule prior to the phase-in date, but adopted SEC filing within the next two months and were reinstated to the OTCBB. $\mathrm{N}$ is the number of firms in the subsample. Because they had a 60-day period between the Effective "E" date and the Phase-in date, rather than a 30-day period, Banks and Insurance Companies are dropped from this analysis. 
Table 6

Long-term Shifts in Liquidity Measures

\begin{tabular}{|c|c|c|c|}
\hline \multirow{2}{*}{\multicolumn{4}{|c|}{ 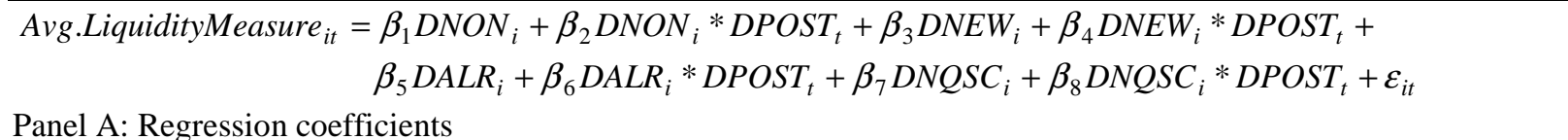 }} \\
\hline & & & \\
\hline Firms and time periods & Bid-ask Spread & Monthly Turnover (\%) & Percent of Days Traded \\
\hline Noncompliant in $1998 / 9$ & $0.606^{* * *}$ & $1.322^{* * * *}$ & $0.342^{* * *}$ \\
\hline Incremental level in 2000/1 & $0.118^{* * *}$ & $-0.534^{* * *}$ & $-0.075^{* * *}$ \\
\hline Newly Compliant in $1998 / 9$ & $0.528^{* * *}$ & $1.988^{* * *}$ & $0.421^{* * *}$ \\
\hline Incremental level in $2000 / 1$ & $-0.257^{* * *}$ & $0.720^{* * *}$ & $0.070^{* * * *}$ \\
\hline Already Compliant in $1998 / 9$ & $0.338^{* * *}$ & $2.049^{* * *}$ & $0.506^{* * *}$ \\
\hline Incremental level in $2000 / 1$ & $-0.069^{* * *}$ & $0.221^{*}$ & -0.008 \\
\hline NASDAQ Small Cap in $1998 / 9$ & $0.085^{* * *}$ & $4.780^{* * *}$ & $0.743^{* * *}$ \\
\hline Incremental level in 2000/1 & $0.094^{* * *}$ & $-0.834^{* * *}$ & -0.009 \\
\hline $\mathrm{N}$ & $\begin{array}{c}2988 \\
(1069 / 423 / 1090)\end{array}$ & $\begin{array}{c}3765 \\
(1587 / 590 / 1033)\end{array}$ & $\begin{array}{c}3782 \\
(1595 / 598 / 1034)\end{array}$ \\
\hline
\end{tabular}

Panel B: F-tests for differences in coefficients

Difference in Incremental Levels:

\begin{tabular}{|c|c|c|c|}
\hline & & & \\
\hline Noncompliant - Newly Compliant & $0.375^{\text {*** }}$ & $-1.254^{* * *}$ & $-0.145^{\text {*** }}$ \\
\hline Noncompliant - Already Compliant & $0.187^{* * *}$ & $-0.755^{* * * *}$ & $-0.067^{* * * *}$ \\
\hline Newly Compliant- Already Compliant & $-0.188^{* * *}$ & $0.499^{* *}$ & $0.078^{* * *}$ \\
\hline Noncompliant - NASDAQ Small Cap & 0.024 & 0.300 & $-0.066^{* * *}$ \\
\hline Newly Compliant - NASDAQ Small Cap & $-0.351^{* * *}$ & $1.554^{* * *}$ & $0.079^{* * *}$ \\
\hline Already Compliant - NASDAQ Small Cap & $-0.163^{* * *}$ & $1.055^{* * *}$ & 0.001 \\
\hline \multicolumn{4}{|l|}{ Difference in 1998/9 Levels: } \\
\hline Noncompliant - Newly Compliant & $0.078^{* * *}$ & $-0.666^{* * *}$ & $-0.079^{* * *}$ \\
\hline Noncompliant - Already Compliant & $0.268^{* * *}$ & $-0.727^{* * *}$ & $-0.164^{* * *}$ \\
\hline Newly Compliant- Already Compliant & $0.190^{* * *}$ & -0.061 & $-0.085^{* * *}$ \\
\hline \multicolumn{4}{|l|}{ Difference in 2000/1 Levels: } \\
\hline Noncompliant - Newly Compliant & $0.453^{* * *}$ & $-1.920^{* * *}$ & $-0.224^{* * *}$ \\
\hline Noncompliant - Already Compliant & $0.455^{* * *}$ & $-1.482^{* * *}$ & $-0.231^{* * * *}$ \\
\hline Newly Compliant- Already Compliant & 0.002 & $0.438^{* * *}$ & -0.007 \\
\hline
\end{tabular}

***,**,* Significantly different from zero at the 0.01, 0.05, 0.10 level, respectively, using a two-tailed test

The table presents results from a regression of average liquidity measures on indicators for firm type interacted with the time period. The Bid-ask Spread is computed as the difference between the closing bid and ask prices, divided by the midpoint of the spread. Monthly Turnover (\%) is computed as monthly share volume divided by average monthly shares outstanding, times 100. Percent of Days Traded is the percentage of trading days in a month with nonzero volume. Noncompliant firms include all non-SEC-filers in 1998 that did not comply with SEC filing requirements and were dropped to the Pink Sheets. Newly Compliant firms are non-SEC-filers in 1998 that adopt SEC filing because of the eligibility rule. Already Compliant firms were already SEC filers in 1998 and passed the initial compliance test. NASDAQ Small Cap firms serve as a benchmark. $\mathrm{N}$ is the number of sample firms and, in parentheses, the number of Non-, Newly, and Already Compliant firms, respectively. Spreads (turnover and days traded) are averaged over the three-month (six-month) period Oct.-Dec. 1998 (Dec. 1998-May 1999), before the rule phase-in, and Oct.-Dec. 2000 (Dec. 2000-May 2001), after the completion of the phase-in. Firms must have observations in both periods to be included in the sample. The Incremental Level in 2000/1 indicates the difference in the average liquidity measure between 1998/9 and 2000/1. Panel A presents regression coefficients and Panel B presents F-tests comparing coefficients. 